\title{
Treatment of Tongue Cancer in Patient with Fanconi's Anemia
}

\author{
Seung-Hun Lee, Hee-Sung Park, Jae Won Chang, and Bon Seok Koo \\ Department of Otorhinolaryngology-Head and Neck Surgery, School of Medicine, Chungnam National University, Daejeon, Korea
}

\section{일반인과 다른 판코니빈혈에서 발생한 설암의 치료}

이승훈 · 박희성 · 장재원 · 구본석

충남대학교 의과대학 이비인후-두경부외과학교실

\author{
Received May 3, 2016 \\ Revised June 22, 2016 \\ Accepted June 28, 2016 \\ Address for correspondence \\ Bon Seok Koo, MD, PhD \\ Department of Otorhinolaryngology- \\ Head and Neck Surgery, \\ School of Medicine, \\ Chungnam National University, \\ 282 Munhwa-ro, Jung-gu, \\ Daejeon 35015, Korea \\ Tel $+82-42-280-7695$ \\ Fax +82-42-253-4059 \\ E-mail bskoo515@cnuh.co.kr
}

Fanconi's anemia is a rare autosomal recessive genetic disorder characterized by congenital abnormalities and anaplastic anemia. Patients with this disorder has predisposition for leukemia, specifically acute myeloid leukemia. Risk for head and neck solid tumors are also increased. Head and neck cancers in patients with Fanconi's anemia are significantly different from those in patients without Fanconi's anemia in frequency, distribution, clinical course, and treatment. Therefore, we report a case of 23-year-old male with Fanconi's anemia, who presented with an oral tongue cancer treated with radical excision, bilateral neck dissection and careful postoperative radiation therapy.

Korean J Otorhinolaryngol-Head Neck Surg 2017;60(9):467-70

Key Words Fanconi's anemia $\cdot$ Tongue cancer.

\section{서 론}

판코니빈혈(Fanconi’s anemia)은 상염색체 열성 유전 질환 으로 약 130000 명 중 한 명에서 발생하는 것으로 알려져 있 는 드문 질환이다. 판코니빈혈은 선천 기형 및 재생불량성 빈 혈을 일으키는 것으로 알려져 있으며, 또한 악성 종양이 발생 할 가능성이 높다.1) 선천 기형은 근골격, 비뇨생식, 신장, 신경 계통 등 다양한 장기에서 나타난다. ${ }^{2)}$ 악성 종양은 백혈병 등 혈액암이 주로 발견되나 고형암도 발견되고 있으며, 특히 두경 부에서 편평상피세포암의 발병위험이 높다고 알려져 있다. ${ }^{3}$ 판코니빈혈에서 발생한 두경부암의 치료 방법은 일반적인 두 경부암과는 차이가 있는 것으로 알려져 있다. 전 세계적으로 판코니빈혈 환자에게서 두경부 악성 종양이 발생한 사례는

This is an Open Access article distributed under the terms of the Creative Commons Attribution Non-Commercial License (http://creativecommons.org/licenses/by-nc/4.0) which permits unrestricted non-commercial use, distribution, and reproduction in any medium, provided the original work is properly cited.
종종 보고되고 있으나, 그 빈도는 극히 드물며 우리나라에서 보고된 경우는 많지 않다. 최근에 저자들은 판코니빈혈로 골 수이식을 시행받은 환자가 설암으로 진단되어 치료받은 증례 를 경험하였기에 치료 시 주의할 점을 문헌 고찰과 함께 보고 하고자 한다.

\section{증 례}

환자는 23세 남자로 출생 당시 양쪽 엄지손가락 및 엄지발 가락에 기형이 있었고 소두증이 있었다. 1994년 재생불량빈혈 을 진단받았고, 1996년 범혈구감소증으로 시행한 유전자 검 사에서 판코니빈혈을 진단받았다. 10년 후 2006년 7월 골수 이식을 시행받았으며 2014년 좌측 설가동부 종물을 주소로 치과 내원하여 시행한 조직검사에서 편평상피세포암으로 확 진되어 본과에 의뢰되었다. 내원 당시 좌측 설가동부를 채우 는 돌출형의 종물의 크기는 약 $3 \times 3 \mathrm{~cm}$ 였으며 전반적인 궤양 
이 있었고 가벼운 접촉에도 쉽게 출혈이 발생하였다(Fig. 1). 경부 CT 및 $\mathrm{MRI}$ 에서 좌측 설부에 약 $3.7 \mathrm{~cm}$ 크기의 조영 증강되는 종물이 관찰되었으며(Fig. $2 \mathrm{~A}$ ), 좌측 경부의 $\mathrm{Ib}$ 지 역에서 조영증강되는 림프절이 관찰되었다(Fig. 2B). 종물은 정 중선까지 근접하여 있었으며 외설근(extrinsic tongue muscle) 을 침범하는 양상이었다. Positron emission tomographyCT에서 원격전이가 의심되는 병변은 보이지 않았다. 수술은 pull-through 접근법을 이용하여 설암의 광범위절제 및 양측 I, II, III 지역 경부절제술을 시행하였고, 전외측대퇴부유리피 판(anterolateral thigh free flap)을 이용하여 재건을 시행하 였다. 수술 후 병리조직소견은 편평상피세포암이었으며(Fig. 3), 침범 깊이는 $1.6 \mathrm{~cm}$ 였고 절제연의 침범은 없었다. 술 전 영 상에서 커져 있었던 동측 $\mathrm{Ib}$ 지역의 림프절은 설암의 전이성 림프절로 확인되었으며, 피막외침범소견이 관찰되었고 반대

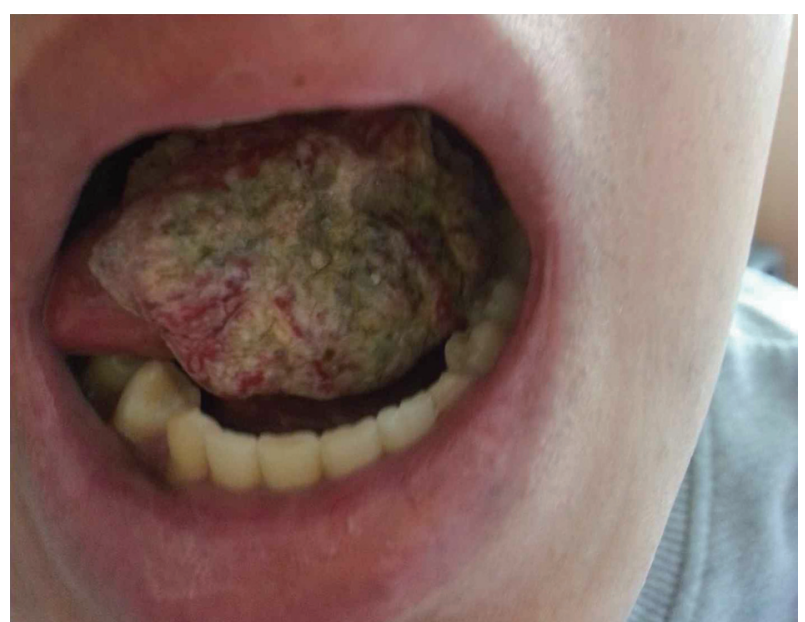

Fig. 1. Gross image. Ulcerofungating mass in left lateral aspect of oral tongue.
측 림프절에 전이성 림프절은 발견되지 않았다. 판코니빈혈 에서 발생한 설암의 특성 때문에 술 후 보조 치료로 항암방 사선 치료 대신 환자의 상태를 주의 깊게 관찰하면서 방사선 치료를 시행하였다. 원발병소 및 동측 경부에 총 $5670 \mathrm{cGy}$ 의 방사선 치료를 받은 후 현재까지 약 1 년간 재발 없이 외래 추 적관찰 중이다.

\section{고 찰}

판코니빈혈은 다양한 임상증상을 보여주며 골격이나 심장, 신장, 눈 등에 선천성 기형을 동반하는 것으로 알려져 있다. 특히 많은 수의 환자들에서 범혈구감소증이 나타나며 골수 부전으로 진행되어 골수이식을 받는 경우가 많다. 또한 판코 니빈혈이 있는 환자에서 백혈병이나 두경부암 등의 악성 종

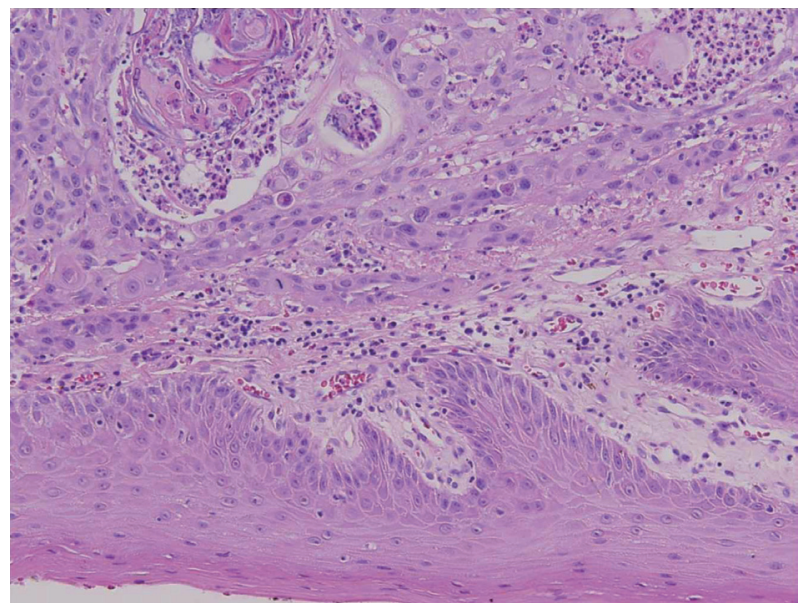

Fig. 3. Pathologic findings. Moderate differentiated keratinizing squamous cell carcinoma $(H \& E, \times 100)$.

Fig. 2. Preoperative enhanced neck computed tomography. Heterogeneously enhancing soft tissue lesion (arrow) (about 3.7 $\mathrm{cm}$ in size) in the left lateral oral tongue (A). A small enhancing lymph node with intranodal necrosis in the left neck level lb area (arrow) (B).
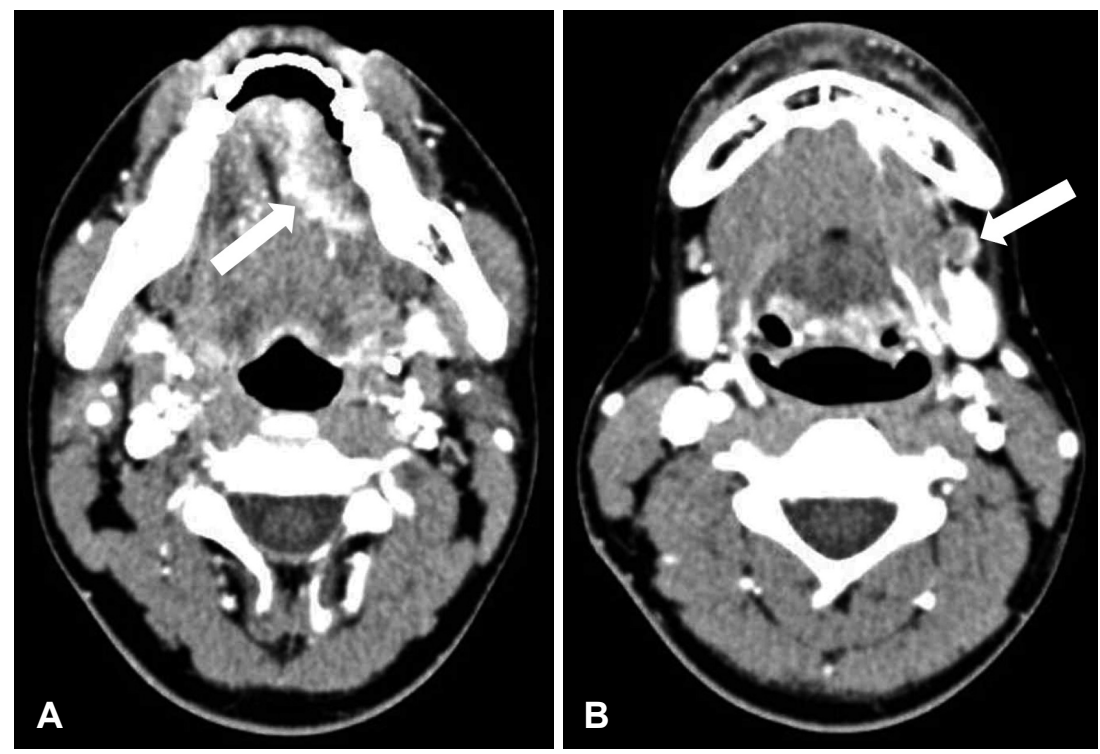
양 발생 위험성이 높은 것으로 알려져 있으며, 특히 골수이식 을 받은 환자에서 위험성이 더욱 높은 것으로 알려져 있다. ${ }^{4.5)}$ 판코니빈혈에서 악성 종양의 발생빈도가 높은 원인은 유전체 의 결합이 유지되지 못하여 염색체의 불안정성이 증가하고 $\mathrm{DNA}$ 복구 과정에 결함이 발생하기 때문으로 알려져 있다. 1927년 판코니빈혈이 악성 종양과 관련이 있음이 보고된 이 후, 두경부 영역에서 1966년 Esparza와 Thompson ${ }^{6}$ 에 의해 처음으로 악성 종양이 보고되었다. 판코니빈혈에서 두경부암 은 혈액암 다음으로 잘 발생하는 암으로 판코니빈혈 환자의 $3 \sim 5 \%$ 에서 발생하며, ${ }^{7,8)}$ 일반인에 비해 500 700배 정도 두경 부암 발생확률이 높은 것으로 알려져 있다. 또한 2년 생존율 도 $49 \%$ 로 일반인에서 발생한 두경부암의 생존율인 $70 \%$ 보 다 낮다. $2,9,10)$

조직학적으로 판코니빈혈 환자에서 발생한 두경부암은 일 반인에서 발생한 두경부암과 비슷하지만, 발생 빈도나 분포, 임상적 진행과정은 의미 있게 차이가 있으며 치료의 방향에 있어서도 차이가 있다. 판코니빈혈에서 두경부암이 발생한 중위연령은 16 31세이며, 이는 일반인에서 두경부암 발생의 중위연령이 53세인 것과 비교하면, 판코니빈혈 환자에서 두 경부암이 매우 어린 나이에 발병하는 경향이 있는 것을 알 수 있다.10,11) 그러므로 판코니빈혈로 골수이식 등의 치료를 받은 환자들은 40세 이전의 젊은 나이에 두경부암이 발생할 수 있 으므로 항상 주의 깊게 추적관찰을 하여야 할 것으로 생각 한다. 본 증례 환자도 기존의 보고와 유사하게 판코니빈혈을 진단받은 23세의 젊은 환자에서 발생한 설암이었다. 또한 조 기에 림프절에 전이되고 주변 조직 침범도 더 빨리 진행되어 일반적인 두경부암과 비교하여 보다 공격적인 경향이 있다. 본 증례의 환자에서도 주위로 침윤하는 양상의 원발병소와 함께, 피막외침범이 있는 림프절 전이를 확인할 수 있었다.

일반인에서 발생한 두경부암의 치료에 수술과 필요에 따라 서 항암방사선 요법을 적용할 수 있지만, 판코니빈혈 환자는 $\mathrm{DNA}$ 의 손상을 복구하는 기전이 일반인에 비해서 취약하기 때문에 항암방사선 치료로 인한 부작용이 일반인에 비해 심 각할 수 있고, 때로는 치명적일 수 있다. 그러나, 수술적 치료 는 수술 자체로 인한 부작용이나 후유증이 판코니빈혈 환자 에서 일반인에 비해 유의하게 증가하지는 않으므로 판코니빈 혈이 있는 환자에서 발생한 두경부암의 치료에서는 수술이 최우선적으로 고려되어야 한다. ${ }^{11)}$

항암제의 선택에 있어서도, 일반적으로 두경부암의 항암치 료 약제로는 알킬화약물인 cisplatin과 항대사물질인 5-FU 가 일차적으로 선택되지만, 판코니빈혈 환자에서 비선택적으 로 세포의 DNA를 손상시키는 항암제들은 일반인에 비해 보 다 심각하고, 치명적인 부작용을 유발할 가능성이 있어 사용
하지 않는다. 대신 암세포에 보다 선택적인 표적치료제인 cetuximab을 일차적으로 고려할 수 있으나, 이에 대해서는 더 많은 연구가 필요할 것으로 생각된다. ${ }^{12)}$

방사선 치료를 시행할 때도 판코니빈혈 환자에서는 특별히 유의해야 한다. Kutler 등긔 보고에 따르면, 방사선 치료를 받은 판코니빈혈 환자 6명 중 4명에서 중요한 부작용이 발견 되었고 그중 2명은 방사선 치료 때문에 사망하였다. 그러므 로 판코니빈혈 환자에서는 부작용을 최소화하기 위하여 첫 째, 세기변조 방사선치료(intensity modulated radiation therapy)를 우선적으로 고려해야 하며, 둘째, 부작용이 일어나지 않는지 세밀하고 적극적으로 검진하여 조기에 대응해야 한 다. 특히 방사선이 조사된 부위에 뿐만 아니라 골수 부전이 나 전신 진균 감염 등의 전신 부작용에 대해서도 세밀한 감 시가 필요하다. 만약 생명을 위협할 정도의 부작용이 발견되 면 방사선 치료를 중단하거나 연기해야 한다. 본 환자에 있어 서도 피막 외 침범이 있는 림프절 전이가 있어 진료지침에 따 르면 항암방사선 치료가 권장되지만, 환자의 특수한 상황을 고려하여 항암치료 없이 수술 후 주의 깊게 관찰하면서 방사 선 치료만 시행하였다.

원발부위와 림프절 청소술에 대한 수술 원칙은 일반적인 환자의 그것과 다르지 않다. 일반적인 두경부암에서 수술적 제거 후 재건이 필요한데, 판코니빈혈 환자에서도 재건에 대 해서는 제한사항이 없으므로 유리피판이식이 가능하며 본 환 자에서도 수술로 인해 유발된 결손에 대하여 전외측대퇴부유 리피판을 이용하여 재건하여 기능적 소실을 최소화하였다. ${ }^{3,11}$

판코니빈혈 환자에서 발생한 두경부암의 치료는 일반적인 두경부암의 그것과는 차별화되어야 한다. 수술을 할 수 있다 면, 항상 수술치료를 최우선으로 고려해야 하며, 항암방사선 치료가 판코니빈혈 환자들에서는 일반인보다 심각하고 치명 적인 부작용을 유발할 수 있어 이를 추가하는 데 보다 세밀하 고 신중하게 결정해야 한다.

\section{Acknowledgments}

This work was supported by research fund of Chungnam National University.

\section{REFERENCES}

1) Alter BP, Young NS. The bone marrow failure syndromes. In: Nathan DG, Oski SH, Oski FA, editors. Hematology of Infancy and Childhood. Philadelphia: WB Saunders;1998. p.237-335.

2) Swift MR, Hirschhorn K. Fanconi's anemia. Inherited susceptibility to chromosome breakage in various tissues. Ann Intern Med 1966; 65(3):496-503.

3) Kutler DI, Auerbach AD, Satagopan J, Giampietro PF, Batish SD, Huvos AG, et al. High incidence of head and neck squamous cell carcinoma in patients with Fanconi anemia. Arch Otolaryngol Head Neck Surg 2003;129(1):106-12.

4) Alter BP. Fanconi's anemia and malignancies. Am J Hematol 1996; 
53(2):99-110.

5) Socié G, Scieux C, Gluckman E, Soussi T, Clavel C, Saulnier P, et al. Squamous cell carcinomas after allogeneic bone marrow transplantation for aplastic anemia: further evidence of a multistep process. Transplant 1998;66(5):667-70.

6) Esparza A, Thompson WR. Familial hypoplastic anemia with multiple congenital anomalies (Fanconi's syndrome)--report of three cases. Cases presented are of two sisters and a female cousin with complete clinical and post mortem findings. R I Med J 1966;49(2):103-10.

7) Kutler DI, Singh B, Satagopan J, Batish SD, Berwick M, Giampietro $\mathrm{PF}$, et al. A 20-year perspective on the International Fanconi Anemia Registry (IFAR). Blood 2003;101(4):1249-56.

8) Duckworth-Rysiecki G, Hultén M, Mann J, Taylor AM. Clinical and cytogenetic diversity in Fanconi’s anaemia. J Med Genet 1984;21(3): 197-203.

9) Rosenberg PS, Greene MH, Alter BP. Cancer incidence in persons with Fanconi anemia. Blood 2003;101(3):822-6.

10) Alter BP. Cancer in Fanconi anemia, 1927-2001. Cancer 2003;97(2): 425-40.

11) Lustig JP, Lugassy G, Neder A, Sigler E. Head and neck carcinoma in Fanconi's anaemia--report of a case and review of the literature. Eur J Cancer B Oral Oncol 1995;31B(1):68-72.

12) Bonner JA, Harari PM, Giralt J, Azarnia N, Shin DM, Cohen RB, et al. Radiotherapy plus cetuximab for squamous-cell carcinoma of the head and neck. N Engl J Med 2006;354(6):567-78. 